\title{
Sensitivity of Larva Spodoptera litura Against the Density of Spores of Fungi Metarhizium anisopliae on the Onion Plant Red (Allium cepa) in the Laboratory
}

\author{
Brijayanti Halawa $^{1}$, Azwana $^{1}$ \& Ellen L. Panggabean ${ }^{1}$ \\ ${ }^{I}$ Faculty of Agriculture, University of Medan Area, Indonesia \\ halawaumafp@gmail.com
}

\begin{abstract}
Sensitivity of Larva Spodoptera litura Against the Density of Spores of Metarhizium anisopliae Fungi On the Red Onion Plant ", aims to determine the density of Metarhizium anisopliae spores which are effective in controlling the spodoptera litura pests that attack onion plants. This research was conducted by using Randomized Complete Random (RAL) Factorial ie instar larvae and spore density. The parameters observed were behavioral and morphological changes as well as percentage mortality of Spodoptera litura larvae. The results showed that: Changes in behavior and morphology of insects in the form of slow movement, decreased appetite and larval body surface covered by the fungus is light green and dark green. The density of spores of $M$. anisopliae to S. litura pest has a very significant effect on the percentage of S. litura mortality since the age of 1-9 HSA. The percentage of $S$. litura mortality tended to increase with higher spore density of $M$. anisopliae and instar 1-3 being more sensitive instar than instar 4-6 Spodoptera litura larvae. Mortality of S. litura is most prevalent in I1M3 treatment (instar 1-3 with spore density 106).
\end{abstract}

Keywords : sensitivity; density; spores; fungi; mortality

\section{Introduction}

Onions are vegetable commodities which are damaged by farmers as commercial businesses, where all the results are intended to meet market demand. Red onion production in North Sumatra from 2007-2010 tended to increase even though in 2011 there was a decline in production from the previous year. However, the production of shallots in North Sumatra is not enough to meet North Sumatra's consumption. Therefore imports of shallots must always be done to meet these consumption needs (BPS North Sumatra, 2012).

In 2007 imports of shallots were 704,406 tons and in 2011 606,708 tons. This shallot import was carried out through the port of Belawan. Shallots are imported through this Belawan port in addition to meeting North Sumatra's needs to meet the needs of other provinces on the island of Sumatra. As with the development of the amount of production, the area of shallot harvest in North Sumatra also increased from 2007 to 2010 by 380 ha. However, in the period of 2010 to 2011 the area of shallot harvest in North Sumatra decreased from 1,610 hectares in 2010 to 1,335 hectares in 2011. The harvested shallots decreased by 275 hectares.

In North Sumatra there are 9 regencies that produce commodity shallots. In 2011 the largest harvested districts were Simalungun regency with a harvest area of 403 ha, and the second largest harvest area was Dairi district with a harvest area of 316 ha. From the description above it is known that the main problem is the decreasing harvest area in North Sumatra, especially Samosir and Dairi districts. The productivity of shallots in North Sumatra is high. The average productivity of shallots in North Sumatra in 2011 reached $98.9 \mathrm{kw} / \mathrm{ha}$. The highest productivity in Simalungun Regency with productivity of $146.7 \mathrm{kw} /$ ha and the lowest productivity in South Tapanuli district with productivity of only $7.1 \mathrm{kw} / \mathrm{ha}$. 
According to Pitojo 2005 in Ginting 2014, the productivity of shallots developed in North Sumatra reached $74 \mathrm{kw} / \mathrm{ha}$. Red onion has long been developed in Dairi district, especially in the Silahisabungan district. Silahisabungan District is the only sub-district producing commodity onions in Dairi district. Red onion production has decreased significantly. According to one farmer, the main cause of the decline in shallot production is due to prolonged rain and pest attacks. The type of pest that often attacks onion plants is one of them is the caterpillar onion (Spodoptera litura). Loss of yield due to this caterpillar attack can reach $57 \%$ because it occurs from the growth phase to the tuber maturation phase (Nurhayati, 2011). In addition to onion caterpillars, other pests can also reduce onion production. In the dry season, crop losses due to an onion caterpillar attack can reach $100 \%$ if not controlled (Moekasan et al, 2000).

The emergence of problems due to the use of chemical pesticides stimulates the use of non-chemical insecticides as an insecticide that is safe for the environment by utilizing toxic compounds from plants, microbes, or entomopathogenic fungi. Entomopathogenic fungi are one of the potential biological agents to control plant pests. Some entomopathogenic fungi that have been used to control plant pests and vegetables are Metarhizium anisopliae, Beauveria bassiana, Paecilomyces sp., Verticillium sp., And Spicaria sp (Mulyono, 2007).

Some research results show that $\mathrm{M}$. anisopliae is effective in controlling the insect population of the Order of Lepidoptera. S. litura larvae infected with fungus spores with concentrations of spores / $\mathrm{ml}$ to spores / $\mathrm{ml}$ caused the death of Spodoptera litura larvae up to $83 \%$ on day 12 after infection with fungus spores (Prayogo and Tengkano, 2004). Information on the ability of Metarhizium anisopliae to infect eggs S. litura has never been reported.

\section{Methodology}

The materials used in this study were: Spodoptera litura larvae, Metharizium anisopliae, clean water and distilled water, $70 \%$ alcohol, and leeks as larval feed. The tools used in this study are: petri dishes, isolation boxes, bunsen lamps, needle oars, jars, handsprayers, Haemocytometers, microscopes, electric scales, label paper, gauze, rubber bands, test tubes, scissors, paper wrap, aluminum foil, tissues, masks, stationery, and other tools that can be needed when the research is running.

This research was conducted using a Factorial Completely Randomized Design (CRD) Factorial first treatment, namely: Instar Spodoptera litura used, consisting of 2 treatment levels: $\mathrm{I} 1=\mathrm{S}$. litura $3-4$ and $\mathrm{I} 2=\mathrm{S}$. litura instar $5-6$. Whereas the second treatment factor is the density of Metarhizium anisopliae, consisting of 4 treatment levels: M0 = Without using Metarhizium anisopliae, M1 = spore density of Metarhizium anisopliae 102 (25 spores / ml), M2 = spore density of Metarhizium anisopliae $104(50$ spores $/ \mathrm{ml}), \mathrm{M} 3=$ spore density of Metarhizium anisopliae 106 (100 spores / ml) with number of replications 4 replications

Research Material Preparation (1) Armyworm as research material was obtained by searching and collecting grayak caterpillar (Spodoptera litura) larvae from instar fields 3-4 and 5-6, and maintained on shallots. The larvae of each instar are then placed in a jar that is $16 \times 19 \mathrm{~cm}$ in diameter, and fed with fresh red onion leaves free of pesticides. (2) Preparation of Metarhizium anisopliae. The fungus M. anisopliae originated from the collection of Medan 
Food Crops and Horticulture Protection Agency (BPTPH). Then bred on a PDA (Potato Dextrose Agar) in the laboratory of HPT (Plant Disease) in Medan Area. After the age of 14 days the subsequent culture results are calculated for spores and serial dilution methods according to the treatment.

Application of Metarhizium anisopliae on Spodoptera litura Larvae. S. Litura larvae from 10 rearing (rearing) were placed in jars containing 10 grams of fresh onion leaves, then the shallots and larvae in the jar were sprayed with M. anisopliae solution with appropriate spore density $10 \mathrm{ml}$ treatment using hands prayer. The jar is then covered with gauze and observed the state of the test insect. Daily feed is replaced by 10 grams of organic shallots.

Observation parameters in this study include: (1) Morphological Changes and Insect Behavior of S. litura Test. Observation of changes in insect behavior is carried out every day, starting from 1 HSA (Days after application) such as movement, appetite, body color, and others. (2) Percentage of S. litura Insect Mortality. Observations were carried out every day until $100 \%$ of the deaths of S. litura larvae were tested against M. anisopliae fungi. Mortality is calculated using the formula:

$$
P=\frac{\mathrm{A}}{\mathrm{B}} \times 100 \%
$$

Where :

$$
\begin{aligned}
& \mathrm{P}=\text { Percentage of test insect mortality } \\
& \mathrm{A}=\text { Number of dead insects } \\
& \mathrm{B}=\text { number of whole insects / initial insects }
\end{aligned}
$$

If there is a death of the test insect in the control treatment it is corrected by the formula:

Where:

$$
M s=\frac{\mathrm{Mp}-\mathrm{Mk}}{100-\mathrm{Mk}} \times 100 \%
$$

Ms $=$ Percentage of actual mortality

$\mathrm{Mp}=$ Percentage of treatment mortality

$\mathrm{Mk}=$ Percentage of control mortality (Faisal, 2011).

\section{Result and Discussion}

\subsection{Morphological Changes and Behavior of S. litura Insect Tests}

Observation of symptoms of infection of larvae caused by M. anisopliae fungus is carried out every day. From the results of observations there are differences in symptoms of infection with larvae which can be seen in Table 1, namely:

\begin{tabular}{|c|l|}
\hline $\begin{array}{c}\text { Day After } \\
\text { Application } \\
\text { (HSA) }\end{array}$ & \multicolumn{1}{c|}{ Symptoms M. Anisopliae } \\
\hline 1 & Showing symptoms of slow larval movements, reduced appetite \\
\hline $2-3$ & $\begin{array}{l}\text { Slow movement, reduced appetite and dead larvae, the mycelium in } \\
\text { almost all parts of the body of the larva is white }\end{array}$ \\
\hline $3-4$ & $\begin{array}{c}\text { The mycelium covers the larval body, and the color of the fungus is } \\
\text { light green, the body is stiff, movement is slow, appetite decreases }\end{array}$ \\
\hline
\end{tabular}




\begin{tabular}{|l|l|}
\hline $4-6$ & $\begin{array}{l}\text { The mycelium covers the body of the larva with a light green color } \\
\text { fungus, stiff body }\end{array}$ \\
\hline $6-9$ & $\begin{array}{l}\text { The mycelium is dark green, the body becomes rigid hardened, and the } \\
\text { entire surface of the body of the larva is veiled (mummification). }\end{array}$ \\
\hline
\end{tabular}

Table 1. Symptoms of M. anisopliae Fungus Infection in S. litura Larvae

The results showed that $\mathrm{M}$. anisopliae fungus was able to infect and cause mortality of S. litura larvae. Larvae infected with $M$. anisopliae fungus show stiff dead symptoms, then developing white mycelium appears from the surface of the cuticle, and the end of the infection changes the color of the $\mathrm{S}$. litura larvae to dark green. These symptoms are a typical form of M. anisopliae fungus infection, namely green muscardine (Butt et al. 2001).

On day 1 , the symptoms of $\mathrm{M}$. anisopliae have not been shown in the larvae of all treatments. On the second day, the larval movement is slow, appetite decreases, green discoloration becomes whitish (pale), a few days later it turns pale yellow and then the fungal infection begins with soft body parts and the fungal mycelium covers the larva's body then develops throughout the body cavity, after a few days later the larvae turn green and stiff.

This is in accordance with the statement of Situmorang (1990) that insects that are infected with M. anisopliae will initially be pale yellowish in color, the movement becomes sluggish and eating activity decreases. Insects start from soft parts of the body. Conidia enters the body and spreads throughout the body cavity (haemosil) and penetrates the integument. The typical symptom of the fungus $M$. anisopliae is that infected larvae will die hard and stiff, will still not smell.

\subsection{Percentage of Insect Mortality of S. litura Test}

From the list of variance, it can be seen that the effect of spore density had no significant effect on the percentage of mortality in all observations. Different test average percentage of mortality of S. litura larvae due to treatment of fungus spores M. anisopliae can be seen in Table 2.

Table 2. Average Difference Test Percentage of Mortality of S litura Larvae Due to Treatment of Density of Fungus Spores M.

Anisopliae

\begin{tabular}{|c|c|c|c|c|c|c|c|c|c|c|c|c|c|c|c|c|c|}
\hline \multirow{2}{*}{ Perlakuan } & \multicolumn{17}{|c|}{ Notasi Mortalitas (\%) Larva Spodoptera litura } \\
\hline & \multicolumn{2}{|r|}{1} & \multicolumn{2}{|c|}{2} & \multicolumn{2}{|c|}{3} & \multicolumn{2}{|l|}{4} & \multicolumn{2}{|c|}{5} & \multicolumn{2}{|c|}{6} & \multicolumn{2}{|c|}{7} & 8 & \multicolumn{2}{|l|}{9} \\
\hline I1 & 16,98 & B & 13,93 & B & 12,24 & B & 7,03 & a & 7,78 & A & 8,34 & a & 6,71 & $\mathrm{~b}$ & 6,01 & a 4,42 & $\mathrm{~b}$ \\
\hline 12 & 29,49 & A & 32,10 & A & 24,33 & A & 10,21 & $\mathrm{a}$ & 12,05 & A & 9,18 & $\mathrm{a}$ & 11,87 & a & 7,27 & a 10,39 & $\mathrm{a}$ \\
\hline Mo & 3,73 & $\mathrm{C}$ & 4,60 & $\mathrm{C}$ & 3,58 & $\mathrm{BC}$ & 1,50 & B & 2,10 & A & 1,50 & a & 0,71 & $\mathrm{C}$ & 1,50 & a 1,50 & $\mathrm{a}$ \\
\hline M1 & 3,60 & $\mathrm{C}$ & 4,87 & $\mathrm{C}$ & 2,69 & $\mathrm{CD}$ & 1,02 & B & 1,50 & a & 1,50 & a & 2,81 & $\mathrm{C}$ & 1,50 & a 1,50 & $\mathrm{a}$ \\
\hline M2 & 7,38 & A & 8,20 & $\mathrm{Ab}$ & 7,53 & B & 1,50 & B & 2,90 & a & 2,30 & a & 1,34 & $\mathrm{AB}$ & 1,82 & a 2,10 & a \\
\hline M3 & 8,53 & A & 5,35 & A & 4,49 & A & 4,60 & A & 3,41 & a & 3,46 & $\mathrm{a}$ & 4,44 & A & 1,82 & a 2,30 & $\mathrm{a}$ \\
\hline I1Mo & 0,71 & $\mathrm{D}$ & 0,71 & $\mathrm{C}$ & 0,71 & B & 0,71 & $a$ & 0,71 & $\mathrm{a}$ & 0,71 & $\mathrm{a}$ & 0,71 & c & 0,71 & a $\quad 0,71$ & $\mathrm{a}$ \\
\hline I1M1 & 0,71 & D & 0,71 & $\mathrm{C}$ & 0,71 & B & 0,71 & a & 0,71 & a & 0,71 & $\mathrm{a}$ & 0,71 & c & 0,71 & a $\quad 0,71$ & $\mathrm{a}$ \\
\hline I1M2 & 6,85 & C & 8,20 & B & 8,28 & A & 0,71 & A & 3,50 & a & 2,30 & a & 1,34 & $\mathrm{~b}$ & 2,30 & a 0,71 & $\mathrm{a}$ \\
\hline I1M3 & 8,72 & A & 4,31 & $\mathrm{C}$ & 2,54 & B & 4,91 & A & 2,87 & a & 4,63 & a & 3,96 & a & 2,30 & a 2,30 & $\mathrm{a}$ \\
\hline
\end{tabular}




\begin{tabular}{lllllllllllllllllll} 
I2Mo & 6,76 & c & 8,49 & A & 6,44 & A & 2,30 & & 3,50 & a & 2,30 & a & 0,71 & c & 2,30 & a & 2,30 & a \\
I2M1 & 6,49 & c & 9,03 & A & 4,68 & B & 1,34 & A & 2,30 & a & 2,30 & a & 4,91 & a & 2,30 & a & 2,30 & a \\
I2M2 & 7,91 & ab & 8,20 & A & 6,77 & A & 2,30 & A & 2,30 & a & 2,30 & a & 1,34 & b & 1,34 & a & 3,50 & a \\
I2M3 & 8,33 & a & 6,39 & C & 6,44 & A & 4,28 & A & 3,96 & a & 2,30 & a & 4,91 & a & 1,34 & a & 2,30 & a \\
\hline
\end{tabular}

From Table 2 we can see that the treatment of the instar of S. litura larvae had no significant effect on all ages of observations. The treatment of spore density on the percentage of S. litura larvae had a significant effect on the first day and was very real the following day during observation. The results showed that the fungus M.anisopliae was able to infect and cause mortality of Spodoptera litura larvae on all instars, but from the mortality average data in Table 2 it can be seen that the highest mortality was on instars 3-4 (I1).

The results of variance were seen to be the best treatment at concentrations of 106 $(100 / \mathrm{ml})$ and $104(50 / \mathrm{ml})$. The interaction treatment between spore and instar density showed no significant and significant effect on all age groups, the best according to the results of variance, namely I2M2 although not significantly different from other treatments (Table 2). Symptoms of larvae infected with fungus M. anisopliae show stiff dead symptoms, then developing white mycelium appears from the surface of the cuticle, and the end of the infection changes the color of white mycelium to dark green which covers the entire body surface (body) of S. litura larvae.

The results of statistical analysis showed that in 1-9 HSA it was found that the treatment of I1M2, I2M1, and I2M2 at 9 HSA was the largest percentage of mortality with an average mortality of $100 \%$. This proves that M. anisopliae with low concentration has been able to infect $\mathrm{S}$. litura larvae, by showing symptoms of fungi and mortality due to infection due to the presence of fungus produced by fungi (Widiyanti and Muyadiharja, 2004).

Larval mortality causes many fungi as treatments, nematodes, or bacteria. Hadi et al. (2009) states that if spores and protein crystals are eaten by sensitive insects, paralysis will occur resulting in the death of the host. Bacterial crystals will dissolve in the digestive tract, in which tissue the bacteria secrete toxins that can kill insects. Harjaka et al. (2012) stated that the sensitivity of insects to dextruksin varies and the order of Lepidoptera has more sensitivity.

Dekstruksin is produced by fungus during the infection process and has an antifedant effect, is toxic to insects through absorption mechanism on the cuticle. Larval mortality has many causes. The difference in mortality between each instar is due to the susceptibility of these larvae, where the stages of instar larvae 1-3 and 3-5 HSA are very susceptible because they are young and the cuticle layer is still very thin and soft so there is a great chance for the fungus to enter body.

This is supported by the results of Prayogo et al (2005), that young instar larvae, ie instars 1 to 5 were the most susceptible to $\mathrm{M}$. anisopliae fungi compared to the final instar or 6. In general, insects can be infected by M. anisopliae fungus through contact with cuticles , or through gaps between body segments (Vey et al, 1992).

Other factors causing lower infectivity of fungi M. anisopliae are biology of fungi and biology of Spodoptera litura. Fungus M. anisopliae is better known as a fungus that has habitat in soil (soil fungi) so it is more capable if it is applied in the form of conidia in the soil and can survive with its surviving structure. Conversely, when made a suspension in conidial 
water it immediately germines and if it does not immediately occur in contact with the host's cuticle it will not develop and not be infective (Harjaka et al., 2011).

This is in accordance with Prayogo et al. (2005) stated that the application of entomopathogenic fungus needs to be done more than once, especially if pest insects have a life cycle that consists of several instar stages such as S. litura. Repeated applications are also needed to anticipate environmental factors that are less supportive so that the success rate is low.

\section{Conclusion}

1. Spodoptera litura larvae infected with Metarhizium anisopliae show slowing movement changes, decreased appetite, death with a rigid body and then the entire surface of the body is covered with white mycelium and then light green which then turns dark green.

2. Instar which is more sensitive to Metarhizium anisopliae is 3-4 instars compared to instar 5-6.

\section{References}

Ardiansyah. 2007. Hama Ulat Grayak (Spodoptera litura) mengganas. Urip santos. Word Press. http://www.google.co.id/ Hama Ulat Grayak/Spodoptera litura. Diakses pada tanggal 25 Oktober 2010. Pukul 10.30 WIB.

Badan Pusat Statistik, Sumatera Utara, 2012

Desy, dkk. 2013. Uji Patogenisitas Bacillus thuringiensis dan Metarhizium anisopliae Terhadap Mortalitas Spodoptera litura Fabr (Lepidoptera: Noctuidae) Di Laboratorium, Jurnal Agroeteknologi Usu

Dinas Pertanian Tanaman, 2012. Laporan Dinas Pertanian Tanaman tahun 2007/2011, Kabanjahe.

Direktorat Perlindungan Perkebunan.2005. Kebijakan Perlindungan Perkebunan. Jakarta.

Hadisoeganda, W.W., Euis Suryaningsih dan Tony K. Moekasan, 1995. Penyakitdan Hama Bawang Merah dan Cara Pengendaliannya. Dalam Teknologi Bawang Merah. Pusat Penelitian dan Pengembangan Hortikultura. Badan Penelitian dan Pengembangan Pertanian, Jakarta. Hlm.12-13.

Hera. 2007. Ulat Tentara. Penebar Swadaya. Jakarta. Ulat Grayak (Spodoptera litura). Ditjenbun Deptan.go.id http://www.deptan.go.id/ditlinhorti. Diakses pada tanggal 13 November 2010 Pukul 16.00 WIB

Lembaga Pertanian. 2008. Panduan Pelaksanaan Sekolah Lapang Pengelolaan Tanaman Terpadu (SL-PTT) Kedelai. Departemen Pertanian, Jakarta.

Litbang, 2008. Prospek dan Arah Pengembangan Agribisnis Bawang Merah. Diakses dari: http://www.litbang.deptan.go.id.

Laoh, J.H., Puspita, F., dan Hendra. 2003. Kerentanan Larva Spodoptera litura F. Terhadap Virus Nuklear Polyhedrosis.Jurnal Natur Indonesia Jurusan Agronomi Faperta, Pekanbaru 5 (2): 145-151.

Marwoto dan Suharsono.2008. Pengendalian Hama Terpadu Dan Implementasinya Di Indonesia. Gadjah Mada University Press. Yogyakarta. 
Moekasan, T.K., L. Prabaningrum, dan M.L. Ratnawati, 2000. Penerapan PHT pada Sistem Tanaman Tumpang Gilir Bawang Merah dan Cabai. Balai Penelitian Tanaman Sayuran. Pusat Penelitian dan Pengembangan Hortikultura. Badan Penelitian dan Pengembangan Pertanian, Jakarta. Hlm. 4-5, 30.

Pangestiningsih, Yuswani,. 2008. Uji patogenisitas Bacillus thuringiensis dan Metarhizium anisopliae terhadap mortalitas Spodoptera litura Fabr (Lepidoptera: Noctuidae) Di Laboratorium. Jurnal Agroekoteknologi.

Prayogo, Y, W. Tengkano, dan Marwoto, 2004, Prospek Cendawan Entomopatogen Metarhizium anisopliae untuk Mengendalikan Ulat Grayak Spodoptera litura pada Kedelai. Balai Penelitian Tanaman Kacang-kacangan dan Umbi-umbian.Malang. 